\title{
Proekologiczne rozwiq̨zania w Miejskim Przedsiębiorstwie Komunikacyjnym S.A. w Krakowie
}

\section{Proecological Solutions in Miejskie Przedsiębiorstwo Komunikacyine S.A. in Krakow (Poland)}

\begin{abstract}
Streszczenie: Celem artykułu jest przedstawienie rozwiązań proekologicznych zastosowanych w Miejskim Przedsiębiorstwie Komunikacyjnym w Krakowie, aby poprawić jakość i komfort życia mieszkańców miasta. Kraków jako miasto prężnie rozwijające się zmaga się z problemem dużego zanieczyszczenia powietrza, dotyczącego zwłaszcza wysokiego stężenia pyłu PM10. Głównym źródłem powstawania PM10 w miastach europejskich jest ruch drogowy (silniki wysokoprężne bez filtrów cząstek stałych) oraz tzw. niska emisja. Miejskie Przedsiębiorstwo Komunikacyjne w Krakowie od lat stara się poszerzać działania na rzecz poprawy jakości stanu środowiska, wdrażając z roku na rok coraz nowocześniejsze rozwiązania ekologiczne. Potwierdzeniem skuteczności tych działań jest wiele wyróżnień, jakie przedsiębiorstwo dostaje w podziękowaniu za proekologiczną działalność. Przykładem może być nagroda EkoJanosik przyznawana przez Krajową Radę Ekologiczną oraz statuetka Lidera Transportu Publicznego, jaką w 2018 roku prezydent Krakowa odebrał z rąk Polskiego Związku Pracodawców Transportu Publicznego. Do realizacji celu opracowania zastosowano analizę i ocenę działań Miejskiego Przedsiębiorstwa Komunikacyjnego w Krakowie na rzecz ekologii wraz z krytyczną kwerendą dostępnej literatury.
\end{abstract}

\begin{abstract}
The aim of the article is to present proecological solutions applied in Miejskie Przedsiębiorstwo Komunikacyjne w Krakowie (Municipal Transport Services in Krakow) in order to improve the quality and comfort of city residents' life. Krakow as a dynamically developing city struggles with the problem of significant air pollution concerning mainly the increased concentration of PM10 dust. The main source of PM10 in European cities is road traffic (compression-ignition engines without diesel particulate filters) as well as the so-called low-stack emission. For years, Miejskie Przedsiębiorstwo Komunikacyjne in Krakow has been trying to enhance activities for the improvement of the state of the environment, implementing year by year ever up-to-date ecological solutions. The enterprise has received numerous awards acknowledging its ecological activity which confirms the effectiveness of these activities. Examples include the EKOJANOSIK award granted by National Ecological Council) and statuette of Public Transport Leader presented in 2018 to the President of Krakow by the Polish Union of Public Transport Employers. For realising the aim of this report, analysis as well as evaluation of the activities of Miejskie Przedsiębiorstwo Komunikacyjne in Krakow in the context of ecology were used, along with critical research of available literature.
\end{abstract}

Słowa kluczowe: autobus; ekologia; Kraków; transport; tramwaj

Keywords: bus; ecology; Krakow; transport; tram 
Otrzymano: 1 grudnia 2019

Received: 1 December 2019

Zaakceptowano: 5 lutego 2020

Accepted: 5 February 2020

Sugerowana cytacja / Suggested citation:

Janczarska-Bergel, K. (2020). Proekologiczne rozwiązania w Miejskim Przedsiębiorstwie Komunikacyjnym S.A. w Krakowie. Prace Komisji Geografii Przemysłu Polskiego Towarzystwa Geograficznego, 34(1), $124-137$. doi: $10.24917 / 20801653.341 .9$

\section{WSTĘP}

Rosnąca liczba ludności w aglomeracjach miejskich, a co za tym idzie silna urbanizacja, jest jednym z najbardziej dominujących procesów we współczesnej przestrzeni społeczno-ekonomicznej na świecie. Bardzo duże znaczenie w rozwoju aglomeracji miejskich ma sprawnie i dobrze zorganizowany transport - zwłaszcza publiczny, umożliwiający podróżowanie codziennie tysiącom pasażerów zarówno w obrębie miasta, jak i poza nim (Bogacki, Bździuch, 2017). Potoki pasażerskie w Polsce zazwyczaj realizowane są przez transport szynowy (tramwaje), autobusowy, szybką kolej aglomeracyjną i metro. Sprawność i logistyka systemu transportowego wpływa na atrakcyjność miasta, bez którego jego wzrost gospodarczy byłby nie tylko utrudniony, lecz wręcz niemożliwy.

Jednak agresywna ekspansja przestrzenna miast pociąga za sobą wiele negatywnych aspektów, takich jak: hałas, zanieczyszczenie środowiska, wypadki, degradacja krajobrazu oraz drgania (Korneć, 2018). Szkodliwe oddziaływanie transportu miejskiego na środowisko jest zagadnieniem coraz częściej poruszanym na arenie międzynarodowej, zwłaszcza w tematyce ekologii oraz ochrony przyrody i kurczących się pokładów paliw nieodnawialnych.

Jednym z głównych powodów rozważań nad ekologicznym transportem publicznym (zwłaszcza w Krakowie) jest poważny problem zanieczyszczenia powierza. Związki chemiczne wpływające na jego jakość pochodzą z wielu źródeł (m.in. paleniska domowe), lecz mimo wszystko spory udział w ich wytwarzaniu ma sam transport (silniki spalinowe, ścieranie okładzin hamulcowych, opon oraz nawierzchni jezdni) (Guciewski, Jóźwiak, 2018). Rosnący popyt na usługi transportowe wymusza na ich organizatorach i wykonawcach zastosowanie coraz nowszych i skutecznych technologii, ograniczających pogorszenie komfortu i jakości życia mieszkańców bezpośrednio przez transport. Kraków jako jedno z pierwszych miast w 1993 roku opracował i zaakceptował regulację prawną „Polityka transportowa dla Krakowa”. Jest ona kontynuowana do czasów współczesnych w formie zaktualizowanej po wstąpieniu Polski do Unii Europejskiej.

Wspólnota europejska umożliwia rozwój rozwiązań proekologicznych w transporcie miejskim dzięki ogromnym nakładom finansowym przeznaczonym na ten cel. Warto zaznaczyć, że największa część środków pieniężnych polityki transportowej skierowana jest właśnie na ochronę środowiska i podniesienie jakości życia mieszkańców miasta (Starowicz, 2004).

Celem artykułu jest przedstawienie innowacji ekologicznych wprowadzonych przez Miejskie Przedsiębiorstwo Komunikacyjne w Krakowie, niezbędnych do poprawy środowiska i jakości powietrza w mieście. Sprawnie i ekologicznie funkcjonujący transport publiczny może wpłynąć na sukcesywną rezygnację z indywidualnych środków lokomocji. Nowoczesny tabor, spełniający najwyższe europejskie normy, włączając w to 
autobusy elektryczne i tramwaje, zdecydowanie ogranicza negatywne oddziaływanie na powietrze zanieczyszczeń pochodzących z tradycyjnych silników spalinowych. Ponadto rekuperacja energii wykorzystana we flocie tramwajowej umożliwia mniejsze zużycie energii elektrycznej. Działania MPK S.A. w Krakowie są kompromisem pomiędzy racjami społecznymi, ekonomicznymi oraz ekologicznymi, łącząc komfort, bezpieczeństwo oraz dbałość o środowisko naturalne.

\section{ZANIECZYSZCZENIE POWIETRZA W KRAKOWIE}

Rozwój ekonomiczny każdej aglomeracji ściśle powiązany jest z rosnącą potrzebą transportu, a co za tym idzie, rozbudową infrastruktury i usług transportowych. Jednakże rozwój miejskiej działalności transportowej jest postrzegany jako jeden z głównych czynników pogarszających stan środowiska naturalnego oraz obniżających jakość życia mieszkańców miasta ze względu na zanieczyszczenia oraz hałas. Szczególnie dużą rolę w zanieczyszczeniu powietrza odgrywają substancje powstające przy spalaniu paliw w silnikach spalinowych, takie jak pyły zawieszone (PM2,5 i PM10), sadza i dwutlenek azotu (Filipowicz, Filipowicz, Zaprawa, 2017). Inne procesy wpływające na jakość powietrza pochodzące $\mathrm{z}$ transportu to ścieranie asfaltu, opon samochodowych oraz okładzin hamulców.

Ostatnie lata pokazały, że normy jakości powietrza były przekroczone praktycznie na całym obszarze Polski. Zawyżone stężenie pyłu zawieszonego PM10 i PM2,5 zanotowano zwłaszcza w województwach: małopolskim, łódzkim oraz śląskim. Polska notuje jedne z najwyższych stężeń tych substancji w całej Unii Europejskiej (Kuchcik, Milewski, 2018). Europejska Agencja Środowiska poinformowała, że aż sześć polskich miast, w tym Kraków, jest w pierwszej dziesiątce miast o największym udziale dni w roku z przekroczeniem dopuszczalnego stężenia dobowego pyłów zawieszonych (Kostrz, Satora, 2017). Raport o stanie środowiska $w$ województwie małopolskim $w 2016$ roku (2019) wskazuje, że głównymi czynnikami wpływającymi na zły stan powietrza w aglomeracji krakowskiej są źródła emisji pochodzące z przemysłu, jednostek komunalno-bytowych, komunikacji, warunki topograficzne utrudniające „przewietrzanie” miasta oraz napływ substancji pyłowych z województwa śląskiego.

Strategia rozwoju Małopolski zakłada poprawę jakości powietrza do 2020 roku przez sukcesywną redukcję produkcji zanieczyszczeń, zwłaszcza w transporcie, ogrzewaniu indywidualnym oraz dzięki wzrostowi wykorzystania paliw alternatywnych. Pomiary Wojewódzkiego Inspektoratu Ochrony Środowiska (WIOŚ) w Krakowie wykazały największe stężenie pyłu PM10 i PM 2,5 na stacji komunikacyjnej przy alei Krasińskiego (przekroczenie o 282\% wartości dopuszczalnej), a więc w miejscu o jednym z najwyższych natężeń transportu samochodowego w Krakowie (WIOŚ, 2018). Ograniczenie emisji szkodliwych związków chemicznych z transportu (także miejskiego) oraz indywidualnych prywatnych palenisk domowych wydaje się kluczowym problemem do rozwiązania w najbliższych latach dla aglomeracji krakowskiej.

\section{TRANSPORT MIEJSKI WOBEC ZRÓWNOWAŻONEGO ROZWOJU}

Wraz z rozwojem transportu miejskiego, a co za tym idzie, pogorszającą się jakością życia w dużych miastach, naglący staje się problem ograniczenia zanieczyszczeń pochodzących bezpośrednio z transportu. Władze lokalne zmuszone są do reorganizacji 
działań na rzecz bardziej zrównoważonych i skutecznych rozwiązań w całej logistyce miejskiej.

Jednym z głównych aspektów wymagających interwencji jest wciąż wzrastająca na drogach liczba samochodów osobowych. Zachęcenie mieszkańców miasta do pozostawiania swoich aut pod domem i skorzystania z miejskiego transportu publicznego wymaga dużego nakładu pracy oraz indywidualnego podejścia do zagadnienia.

Drugim istotnym tematem środowiskowym jest hałas drogowy. Według danych WHO ponad $200 \mathrm{mln}$ osób populacji europejskiej wystawione jest na negatywne oddziaływanie hałasu wytwarzanego przez transport.

Wielozakresowa zmiana i optymalizacja transportu miejskiego jest konieczna, aby podnieść jakość i komfort życia w dużych aglomeracjach oraz ograniczyć negatywne oddziaływanie na środowisko. Polityka Unii Europejskiej skupia się przede wszystkim na racjonalizacji indywidualnego użytkowania samochodów oraz podniesieniu atrakcyjności miejskiego transportu zbiorowego (Korneć, 2018). Wszystkie tego typu działania noszą nazwę zrównoważonego transportu. Termin ten oznacza wysoką jakość komunikacji, równocześnie powiązaną z dbałością o stan środowiska naturalnego (m.in. ograniczenie emisji szkodliwych gazów, odpadów i hałasu). Tramwaje, metro oraz autobusy elektryczne powinny stanowić trzon nowoczesnej komunikacji dużych miast.

Zrównoważony rozwój w transporcie ma na celu znalezienie kompromisu pomiędzy trzema ważnymi współcześnie aspektami: społecznym, ekonomicznym oraz ekologicznym. Opisując szczegółowiej, transport zrównoważony to taki, który: spełnia normy emisji zanieczyszczeń oraz hałasu, zaspokaja potrzeby mobilności mieszańców danego obszaru, nie zagraża ekosystemom oraz środowisku, jest komfortowy oraz różnorodny, poprawia jakość życia w mieście i jest przystępny finansowo. Dlatego tak ważne jest wykorzystywanie w transporcie miejskim odnawialnych źródeł energii, zakup nowoczesnego i zarazem ekologicznego taboru, rozwój transportu szynowego (metro, tramwaj, szybka kolej aglomeracyjna), a także stosowanie innowacyjnych rozwiązań w zakresie infrastruktury (Fajczak-Kowalska, Rudowska, Ziemiński, 2017).

Polska po wstąpieniu do Unii Europejskiej otrzymała możliwość finansowania rozwoju polityki zrównoważonego rozwoju z funduszy unijnych. Przykładowo na rozwój ekologicznego i niskoemisyjnego transportu zbiorowego przeznaczono w latach 20142020 blisko 2,4 mld euro, 3 mld euro na poprawę infrastruktury drogowej oraz 5 mld euro na szybką kolej miejską (Motowidlak, 2015).

Współcześnie można spotkać wiele opracowań odnoszących się bezpośrednio do modernizacji i rozwoju komunikacji miejskiej w myśl idei zrównoważonego rozwoju. A. Fajczak-Kowalska i M. Kowalska (2017) zajęły się scharakteryzowaniem pabianickiego transportu zbiorowego, akcentując najważniejsze rozwiązania i projekty zgodne z dokumentami strategicznymi (krajowymi oraz unijnymi). Dzięki dofinansowaniu w ramach Regionalnego Programu Województwa Łódzkiego możliwy stał się w latach 2018-2020 zakup niskoemisyjnego oraz hybrydowego taboru, który ma wpłynąć na zmniejszenie hałasu oraz emisję szkodliwych zanieczyszczeń. Ponadto w planach jest modernizacja stacji obsługi pojazdów, wdrożenie nowoczesnego systemu transportowego oraz przebudowa wiat przystankowych.

Z kolei N. Chamier-Gliszczyński (2010) zaprezentował zadania, jakie realizuje miasto Szczecinek. W związku z przystąpieniem do programu CIVITAS władze miasta prowadzą takie zadania, jak: działanie w myśl idei zrównoważonego rozwoju, wzrost wykorzystania paliw alternatywnych, promowanie transportu publicznego, rozwój 
bezpiecznej infrastruktury drogowej i przystankowej oraz energetyczne i środowiskowe innowacje.

M. Rulaff (2013) skupiła się na projekcie „Trolley” jako przykładzie rozwiązania w myśl ekologicznego transportu zbiorowego. Według autorki wprowadzenie trolejbusów jest ekologiczną alternatywą dla tradycyjnych autobusów napędzanych silnikiem Diesla. Jako pojazdy korzystające z energii elektrycznej pochodzącej z sieci trakcyjnej są one oszczędne, bezpieczne i tanie w utrzymaniu. Projekt jest efektem współpracy środowisk międzynarodowych (m.in. Niemcy, Austria, Czechy, Włochy, Polska i Węgry) działających na rzecz popularyzacji taboru trolejbusowego w dużych miastach.

M. Bodzek (2018) opracował artykuł odnoszący się do zamówień publicznych, będących narzędziem wykorzystywanym w rozwoju zrównoważonego transportu zbiorowego. Przedstawił on Kraków jako lidera „zielonych” zamówień publicznych, wyszczególniając zamówienia na ekologiczny, nowoczesny i niskopodłogowy tabor tramwajowy i autobusowy.

\section{POLITYKA ZRÓWNOWAŻONEGO TRANSPORTU W KRAKOWIE}

Efektywna i ekologiczna polityka transportowa jest trzonem komunikacji zbiorowej w dużych aglomeracjach miejskich. Władze Krakowa ponad 25 lat temu jako pierwsze miasto $\mathrm{w}$ Polsce zadeklarowały organizację komunikacji w myśl idei zrównoważonego transportu. Głównymi celami przyjętej strategii było przede wszystkim utworzenie ekologicznego, bezpiecznego i ekonomicznego transportu miejskiego. W 2007 roku w ramach nowelizacji dokumentu opracowano nowe założenia, obejmujące upowszechnienie i wzmocnienie roli transportu zbiorowego w mieście oraz poszerzenie swojej działalności na większy obszar metropolitarny.

Obecnie obowiązuje polityka transportowa sporządzona na lata 2016-2025, w której uwzględniono kolejny ważny aspekt, jakim jest ograniczenie negatywnego oddziaływania transportu na środowisko oraz życie mieszkańców miasta. Kraków - jako jedno z dziewięciu miast europejskich - przystąpił również do programu CH4LLENGE, którego uczestnicy skupiają się m.in. na wymianie informacji oraz wiedzy, a także wspólnym opracowywaniu i wdrażaniu strategii (Bogacki, Bździuch, 2017). Inne ważne dokumenty podpisane przez władze Krakowa na przestrzeni ostatnich lat to również: „Plan utworzenia jednolitego europejskiego obszaru transportu - dążenie do osiągnięcia konkurencyjnego i zasobooszczędnego systemu transportu”, „Plan gospodarki niskoemisyjnej dla Gminy Miejskiej Kraków” oraz „Krajowa polityka miejska 2023”. Wszystkie powyższe strategie odnoszą się również do problemu zanieczyszczenia środowiska, zmniejszenia efektu cieplarnianego oraz energochłonności generowanej przez transport zbiorowy i ładunkowy w Krakowie (Starowicz, 2017).

\section{MiejSkie PrZEdsięBIoRstwo Komunikacyjne W Krakowie}

Miejskie Przedsiębiorstwo Komunikacyjne (MPK) jest spółką powstałą w 1997 roku z reorganizacji i przekształcenia MPK Sp. z.o.o. Głównym celem przedsiębiorstwa jest organizacja oraz prowadzenie usług przewozowych w zakresie miejskiej komunikacji zbiorowej. Dodatkowo spółka zajmuje się działalnością handlową, usługową oraz gospodarczą. Działa na podstawie umowy na świadczenie usług komunikacji miejskiej w Krakowie w zakresie przewozów tramwajowych, autobusowych i usług 
wspomagających (Statut Spółki Akcyjnej, 2019). Umowa ta określa wymagania techniczno-użytkowe dla całego taboru, m.in.: rodzaj podłogi, wygląd, ogrzewanie, klimatyzację, informację pasażerską itd. Ponadto średni wiek wykorzystywanych pojazdów nie powinien być wyższy niż 10 lat. W 2018 roku firma zatrudniała łącznie 2361 osób (705 kierowców, 481 motorniczych, 732 pracowników zaplecza i obsługi oraz 443 pracowników umysłowych) (Zatrudnienie w MPK, 2019). Sprawna współpraca wszystkich jednostek skutkuje efektywnym funkcjonowaniem komunikacji zbiorowej w Krakowie.

Jak wcześniej zostało wspomniane, podstawową działalnością MPK jest zapewnienie przewozów pasażerskich trakcją autobusową i tramwajową. W tym celu w Krakowie działa pięć zajezdni - trzy autobusowe (Bieńczyce, Wola Duchacka oraz Płaszów) i dwie tramwajowe (Podgórze oraz Nowa Huta), dysponujących łącznie 574 autobusami i 295 tramwajami. Aktualny inwentarz taborowy przedstawiono w tabeli 1 (tramwaje) i tabeli 2 (autobusy).

Tabela 1. Inwentarz taborowy zajezdni tramwajowej Podgórze i Nowa Huta w Krakowie

\begin{tabular}{|l|c|l|c|}
\hline \multicolumn{1}{|c|}{ Zajezdnia Podgórze } & Liczba & \multicolumn{1}{c|}{ Zajezdnia Nowa Huta } & Liczba \\
\hline NGT6 & 50 & E1 & 40 \\
\hline NGT8 & 25 & E1+c3 & 12 \\
\hline 2014N (Pesa) & 14 & N8 & 40 \\
\hline E1+c3 & 19 & EU8N & 23 \\
\hline GT8S & 28 & $2014 \mathrm{~N}(\mathrm{Pesa})$ & 20 \\
\hline $2 \times 105 N a$ & 15 & $2 \times 105 \mathrm{Na}$ & 205 \\
\hline łącznie wagonów: & 185 & łącznie wagonów: & 144 \\
\hline łącznie pociągów: & 151 & łącznie pociągów: & 23 \\
\hline
\end{tabular}

Źródło: opracowanie własne na podstawie rozdziału taboru MPK (Rozkład taboru, 2019)

Tabela 2. Inwentarz taborowy zajezdni autobusowej Bieńczyce, Wola Duchacka i Płaszów w Krakowie

\begin{tabular}{|l|c|c|c|}
\hline \multicolumn{1}{|c|}{ Rodzaj autobusu } & $\begin{array}{c}\text { Zajezdnia } \\
\text { Płaszów }\end{array}$ & Zajezdnia Bieńczyce & $\begin{array}{c}\text { Zajezdnia Wola } \\
\text { Duchacka }\end{array}$ \\
\hline Autobus przegubowy & 47 & 51 & 116 \\
\hline Autobus 12-metrowy & 101 & 120 & 76 \\
\hline Autobus 9-metrowy & 3 & 15 & 18 \\
\hline Autobus przegubowy elektryczny & 0 & 0 & 4 \\
\hline Autobus 12-metrowy elektryczny & 0 & 0 & 4 \\
\hline Autobus 9-metrowy elektryczny & 0 & 0 & 237 \\
\hline $\begin{array}{l}\text { Łącznie } \\
\text { wozów }\end{array}$ & 151 & 186 & 4 \\
\hline
\end{tabular}

Źródło: opracowanie własne na podstawie rozdziału taboru MPK (Rozkład taboru, 2019)

Część linii autobusowych obsługiwana jest od 2008 roku przez prywatnego przewoźnika (firma Mobilis), jednakże blisko 90\% należy do Miejskiego Przedsiębiorstwa Komunikacyjnego. Krakowski przewoźnik obsługuje linie autobusowe miejskie, aglomeracyjne, nocne, przyspieszone oraz wspomagające. Łącznie w 2017 roku MPK obsłużyło $402 \mathrm{mln}$ pasażerów na blisko $34 \mathrm{mln}$. W Krakowie utrzymuje się tendencja wzrostowa na liczbę przewożonych pasażerów oraz pracę przewozową. Wymusza to na Miejskim Przedsiębiorstwie Komunikacyjnym w Krakowie rozwój zarówno ilościowy, 
jak i jakościowy, z ograniczeniem wpływu swojej działalności na środowisko naturalne, zwłaszcza zanieczyszczenie powietrza. Przystąpienie do Unii Europejskiej obliguje Polskę z jednej strony do rozwoju komunikacji miejskiej lecz z drugiej nakazuje dostosowanie do coraz ostrzejszych norm środowiskowych.

Krakowski przewoźnik od lat realizuje działania proekologiczne na rzecz poprawy jakości środowiska i co najważniejsze, nie poprzestaje na dotychczasowych rozwiązaniach, ale z roku na rok wdraża nowe i nowocześniejsze.

\section{EKOLOGICZNE ROZWIĄZANIA ZASTOSOWANE W MPK S.A. W KRAKOWIE}

MPK S.A. w Krakowie od wielu lat działa w myśl polityki zrównoważonego transportu. Co roku wdrażane są coraz to nowsze rozwiązania dotyczące zarówno komfortu, jak i ekologii. Współcześnie dla przedsiębiorstwa jest ważne nie tylko ilościowe postrzeganie transportu, ale również jakościowe w stosunku do środowiska i mieszkańców miasta. Problem zanieczyszczeń powietrza i hałasu dotyczy również transportu zbiorowego, co bezpośrednio zmusza firmę do ciągłego rozwoju i podnoszenia jakości swoich usług. Nowa polityka transportowa Krakowa oddziałuje na cały system transportu zbiorowego - pod kątem logistyki, floty autobusowej, tramwajowej oraz infrastruktury.

Miasto oraz MPK S.A. co roku nagradzane są za swoją proekologiczną działalność. Przykładem może być przyznany w 2018 roku dyplom w ramach konkursu EkoJanosik w kategorii „firma transportowo-komunikacyjna”. Wręczony został przedstawicielowi przedsiębiorstwa przez posłów Sejmowej Komisji Ochrony Środowiska. Nagroda honoruje działania podejmowane na rzecz poprawy stanu środowiska regionu oraz podnoszenie świadomości ekologicznej jego mieszkańców. Drugie wyróżnienie przyznał firmie tygodnik „Wprost” w 2019 roku. Laureatami „Orła Wprost” są podmioty mające duży wkład w rozwój gospodarki regionalnej i krajowej (w tym przypadku działania na rzecz ochrony środowiska). 2018 rok to również tytuł „Lidera Transportu Publicznego” w kategorii „transport ekologiczny”. Prezydent miasta Krakowa odebrał statuetkę od Polskiego Związku Pracodawców Transportu Publicznego głównie za zakup ekologicznego taboru autobusowego, spełniającego wszystkie normy europejskie. Warto również zaznaczyć, że elektryczne autobusy zakupione dla MPK w Krakowie (12-metrowy Solaris) otrzymały w 2018 roku tytuł „Bus of the Year” przyznawany przez Stowarzyszenie Europejskich Wydawców Czasopism Branży Pojazdów Użytkowych.

Jednym z głównych celów przedsiębiorstwa jest zmniejszenie uciążliwości transportu dla środowiska i mieszkańców Krakowa. Odbyć ma się to przede wszystkim przez wymianę tradycyjnego, spalinowego taboru na niskoemisyjny. Z ruchu eliminowane są pojazdy niespełniające europejskich norm emisyjnych. MPK skupiło się na promowaniu zwłaszcza autobusów elektrycznych i hybrydowych. W taborze tramwajowym najważniejsze jest ograniczenie hałasu poprzez zakup nowoczesnego taboru oraz modernizację torowisk tramwajowych. Drugim ważnym elementem jest możliwość rekuperacji energii - czyli odzyskiwania prądu w pojazdach z napędem elektrycznym.

Analiza zamieszczona w Biuletynie Informacji Publicznej (Analiza kosztów..., 2019) wykazała, że średni wiek autobusów w MPK S.A. w Krakowie na koniec 2018 roku wynosił 3,7 lat (według umowy podpisanej z miastem ma on nie przekraczać 10 lat). Najstarsze eksploatowane przez przewoźnika są modele Autosan oraz Mercedes Citaro 0530G wyprodukowane w 2009 roku, a najmłodsze zakupione w 2018 roku Volvo Hybrid i Mercedes Citaro C3. Wszystkie autobusy spełniają co najmniej normę spalin 
Fotografia 1. Solarisy Urbino spełniające normę spalin EUR06 na pętli autobusowej „Łagiewniki” w Krakowie

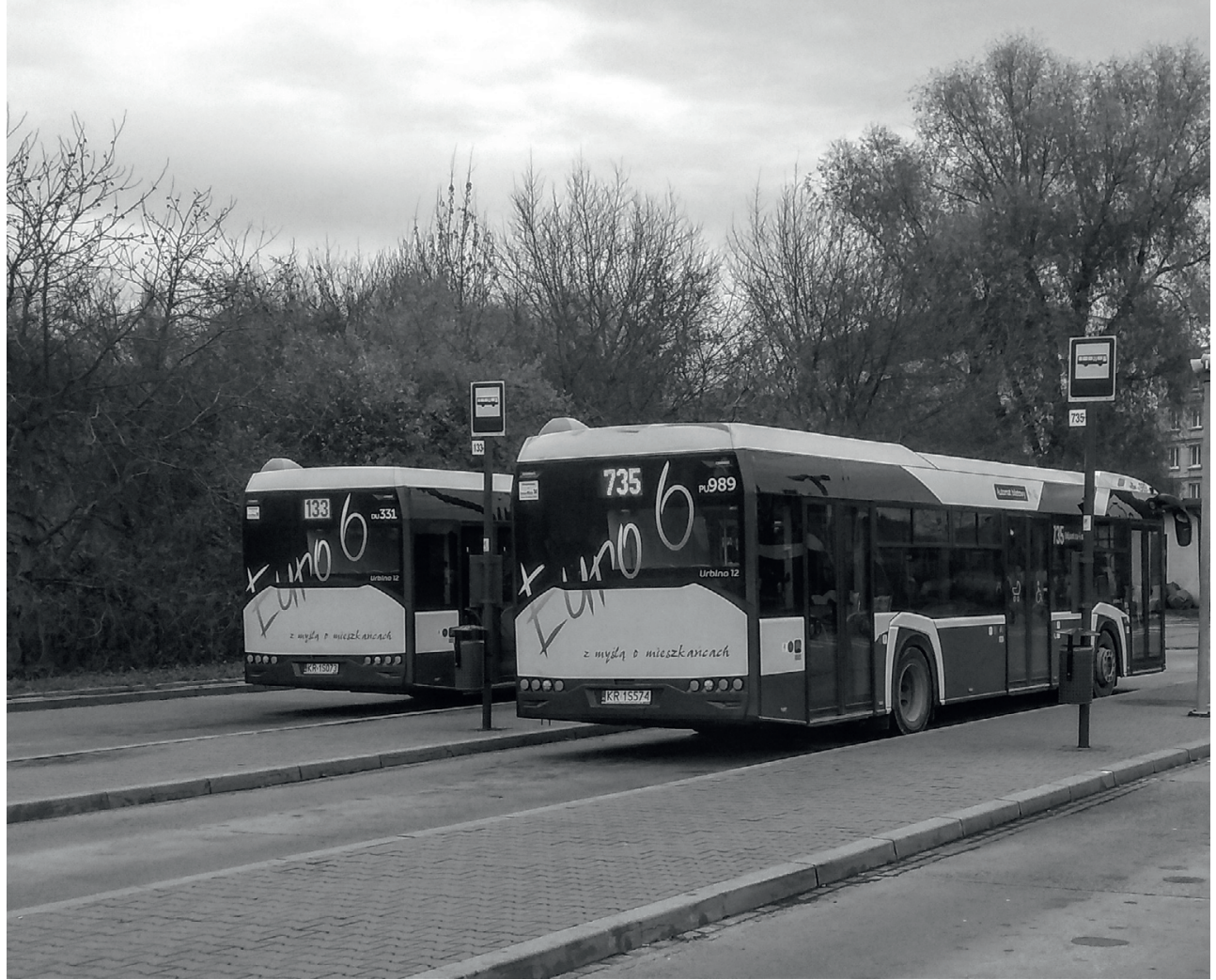

Źródło: Katarzyna Janczarska-Bergel

EUR05, bo zastosowano w nich system obróbki spalin z wykorzystaniem dodatku AdBlue (reduktor szkodliwych tlenków azotu). Najwięcej taboru dostosowano jednak do najwyższej obowiązującej normy EUR06, którą spełniają pojazdy mające poza AdBlue dodatkowo filtr cząstek stałych (DPF). Przykład autobusów z silnikami dostosowanymi do normy EURO6 przedstawia fotografia 1.

W latach 2016-2018 do Krakowa dostarczono blisko 350 autobusów o łącznej wartości prawie 0,5 mld zł. Miasto może się więc pochwalić 100-procentowym ekologicznym taborem, w skład którego wchodzą również autobusy elektryczne i hybrydowe. Największy zakup autobusów z silnikami EUR06 miał miejsce tuż przed Światowymi Dniami Młodzieży w Krakowie w 2016 roku. Dzięki unijnemu wsparciu MPK podpisało umowę z firmą Solaris Bus\&Coach S.A. na pojazdy warte $71 \mathrm{mln}$ zł. Autobusy napędzane są silnikami DAF z systemem rekuperacji energii.

Rok 2018 to również duże inwestycje w nowoczesny i ekologiczny tabor. Na ulice Krakowa wyjechało 161 nowych autobusów zakupionych za 200 mln złotych (78 współfinansowanych z dotacji unijnych). Ponadto na dachach kolejnych sześciu autobusów (dwóch w 2015 roku) zainstalowano system technologii fotowoltaicznej. Dzięki niemu możliwe jest przekształcenie energii słonecznej w elektryczną. Jak można wyczytać na oficjalnej stronie internetowej przedsiębiorstwa, rozwiązanie wspomaga zasilanie kasowników, automatów biletowych, oświetlenia i tablic elektronicznych. Wpływa to 
Fotografia 2. Ładowarka do ładowania autobusów elektrycznych przez pantograf na ul. Pawiej w Krakowie

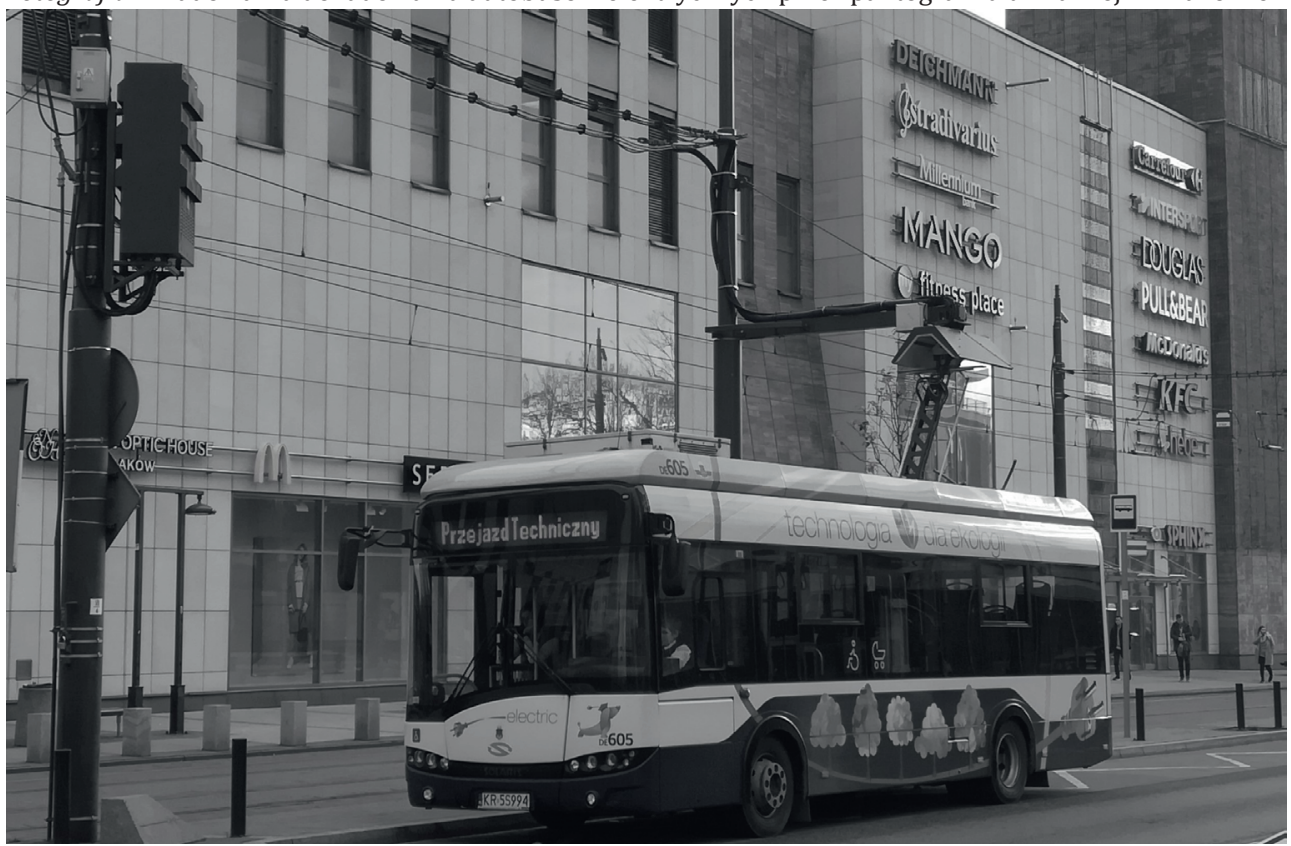

Źródło: Katarzyna Janczarska-Bergel

zdecydowanie na zmniejszenie zużycia paliwa, gdyż prąd powstały z urządzenia pokrywa część zapotrzebowania pojazdu na energię. Panele słoneczne zostały zbudowane z zastosowaniem innowacyjnej technologii (bez użycia szkła). Spełniają wszystkie normy bezpieczeństwa, niepalności i ekologii (MPK SA w Krakowie wyposażyło..., 2019).

Od 2014 roku w użytkowaniu są także autobusy elektryczne. Współcześnie jest to 26 nowoczesnych, niskopodłogowych Solarisów Urbino (12- i 18-metrowych). Obsługują one linię 169/469, 124/424, 166 i 154 w tygodniu, a 503 i 144 w weekend (dostęp do ładowarek na pętlach). Ładowanie ich odbywa się na dwa sposoby - przez pantograf lub złącze typu plug-in. W związku ze zwiększającą się flotą autobusów elektrycznych MPK uruchomiło kilka stacji do ładowania autobusów na terenie Krakowa. Poza Zajezdnią Wola Duchacka ulokowane są one w Łagiewnikach (stacja obsługi tramwajów „Podgórze), Dworcu Głównym Wschód i Zachód oraz na pętlach autobusowych Nowy Bieżanów, Prądnik Biały i Osiedle Podwawelskie. Korzystanie z tych punktów umożliwia doładowanie pojazdu pomiędzy kursami bez konieczności zjazdu na zajezdnie. Przykład tego typu ładowarki został przedstawiony na fotografii 2. Przewoźnik na swoim portalu informuje (Podsumowujemy 2018 rok..., 2019), że został przygotowany i wysłany wniosek o dofinansowanie kolejnych 50 autobusów elektrycznych. Pieniądze na ten cel mają pochodzić z Programu Operacyjnego Infrastruktura i Środowisko na lata 2014-2020. W ramach jego realizacji do Krakowa w 2020 roku zostanie dostarczonych 50 przegubowych autobusów elektrycznych. Na ten moment swoje oferty wysłało dwóch producentów - Evo Bus Polska oraz Solaris. Ich elektryki będą testowane na najbardziej zanieczyszczonych ciągach komunikacyjnych w mieście. Warto zaznaczyć, że Kraków jest pierwszym miastem w Polsce, gdzie uruchomiono regularną linię obsługiwaną tylko przez autobusy elektryczne. 
Dwa z 26 autobusów zostały w 2018 roku wypożyczone na organizowany w Katowicach szczyt klimatyczny COP24 do przewozu jego uczestników.

Od grudnia 2016 roku mieszkańcy Krakowa mogą również podróżować autobusami hybrydowymi wyprodukowanymi przez wcześniej wspomnianą już frmę Solaris Bus\&Coach. To, co wyróżnia je od innych autobusów, to napęd składający się zarówno z silników elektrycznych, jak i niewielkiego spalinowego. Dzięki takiemu silnikowi podczas np. ruszania z miejsca pojazd zużywa mniej paliwa, a tym samym wytwarza mniej zanieczyszczeń. Obecnie Kraków posiada 34 autobusy hybrydowe - 24 Solarisy (9 krótkich i 13 przegubowych) oraz 12 Volvo. Przykład autobusu hybrydowego wykorzystywanego przez MPK w Krakowie przedstawia fotografia 3.

Warto zaznaczyć że każdy z zakupionych autobusów był wcześniej dokładnie testowany przez krakowskiego przewoźnika, zarówno pod kątem niezawodności, jak i wpływu na środowisko. Poza już opisywanymi Solarisami MPK testowało m.in. w 2017 roku autobusy M.A.N. z silnikiem EUR06 i napędzanym CNG oraz w 2018 roku 14,5-metrowe IVECO. 2019 rok to testy elektrycznego przegubowego Solarisa wyposażonego w pantograf do szybkiego ładowania baterii, hybrydowego Mercedesa Benz Citaro i Solarisa z rekuperacją energii elektrycznej. Ustawa o elektromobilości zobowiązuje MPK, aby do 2021 roku autobusy elektryczne stanowiły 5\% floty.

Tabor tramwajowy również z roku na rok jest unowocześniany i odnawiany. Najstarsze kursujące regularnie tramwaje w Krakowie to Konstal 105Na, E1+C3 oraz modernizowane GT8S. Najnowszy to 43-metrowy „Krakowiak” wyprodukowany przez

Fotografia 3. 18-metrowy autobus hybrydowy Solaris obsługujący linię 105 w Krakowie

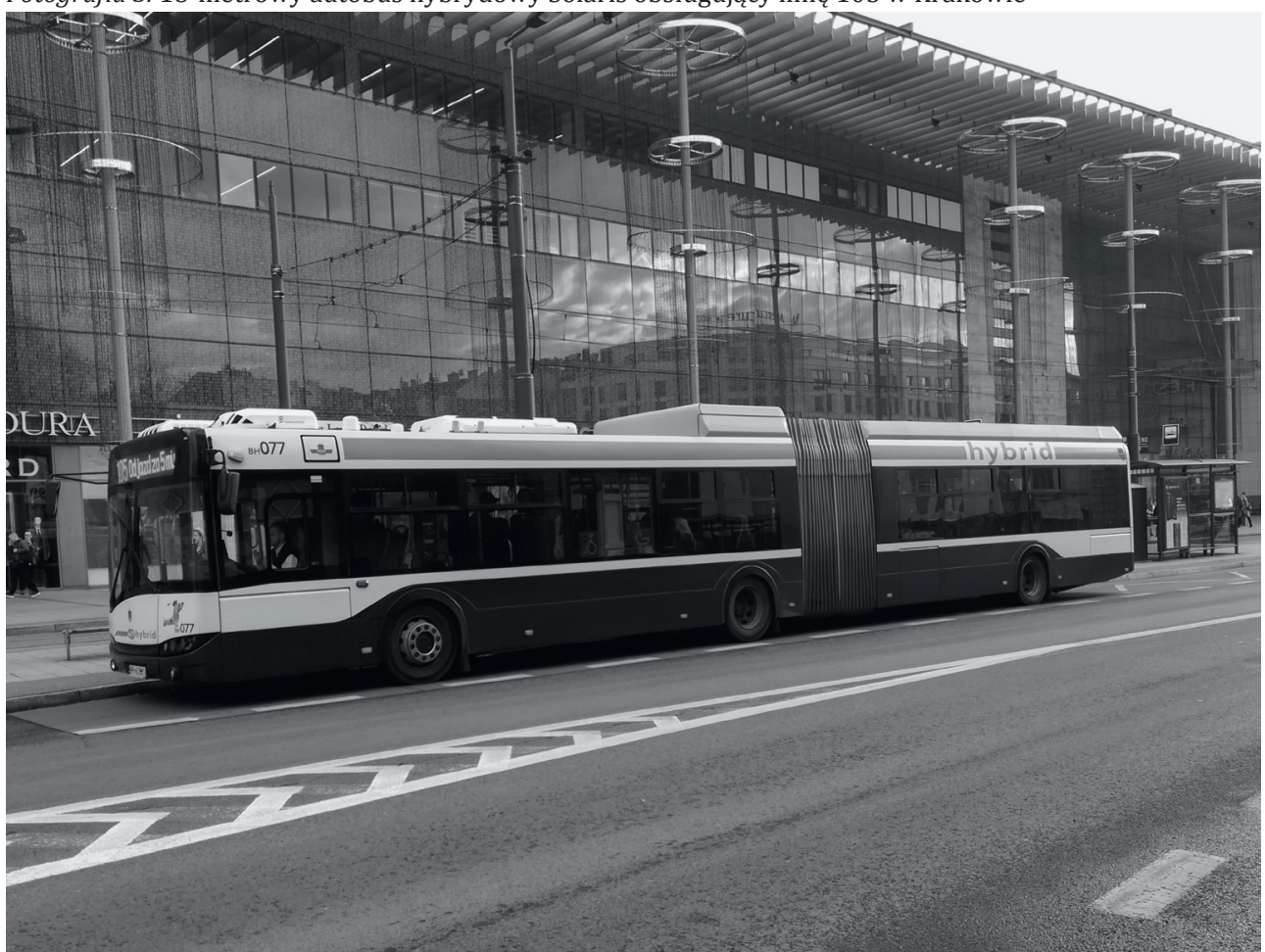

Źródło: Katarzyna Janczarska-Bergel 
Fotografia 4. Tramwaj 2014 N „Krakowiak” wyprodukowany dla Krakowa przez bydgoską firmę PESA

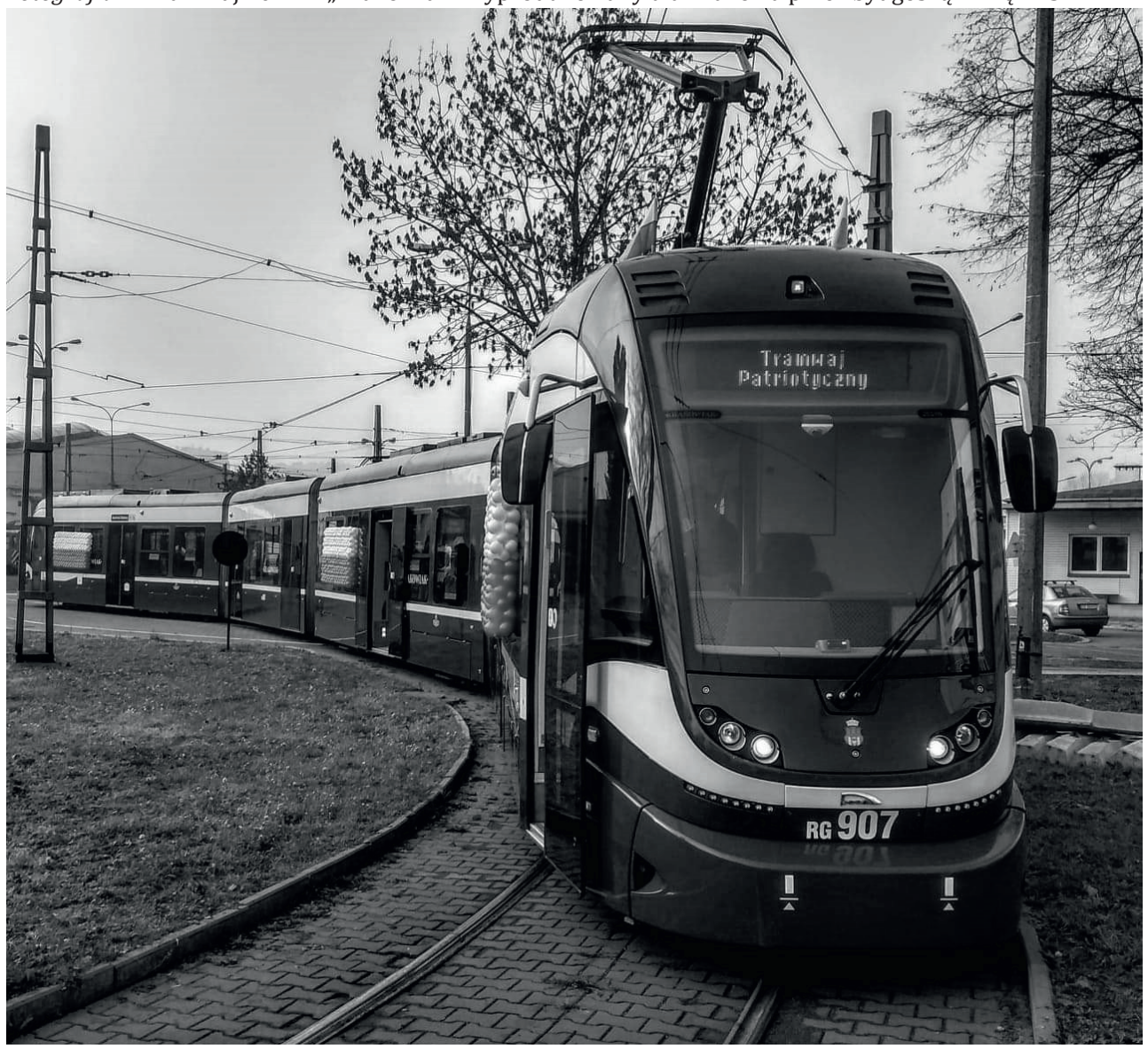

Źródło: Katarzyna Janczarska-Bergel

bydgoską firmę PESA. Nowe generacje tramwajów, takie jak wcześniej wspomniany Krakowiak, NGT6 i NGT8 (Bombardier), wyposażone są w system rekuperacji energii elektrycznej. Takie wagony w 98\% wykorzystują pobraną energię i dodatkowo podczas hamowania zwracają jej część z powrotem do sieci. Wielkość rekuperacji energii dla tych tramwajów to 30\%, z czego 10\% wykorzystywana jest na zasilanie niskonapięciowych urządzeń własnych tramwaju (Jurga, Zając, 2017). Takie rozwiązanie pomaga w ograniczeniu poboru energii elektrycznej, zmniejsza również chwilowe obciążenie trakcji elektrycznej. Nowoczesne tramwaje poza klimatyzacją, niską podłogą oraz wieloma udogodnieniami dla pasażerów, są bardzo ciche. Wpływa to znacznie na zredukowanie hałasu w komunikacji zbiorowej. Krakowiaki np. wyposażone są w system smarowania obrzeży kół, który ma za zadanie ograniczenie ścierania główek szyn, oraz niwelowania efektu drgania i tzw. „piszczenia” podczas skrętu na łuku. Najdłuższy i na ten moment najnowocześniejszy tramwaj w Krakowie przedstawia fotografia 4.

W styczniu 2018 roku MPK podpisało umowę z konsorcjum Stadler Polska i Solaris Bus\&Coach na dostawę 35 niskopodłogowych pojazdów, z możliwością zakupu następnych $15 \mathrm{w}$ kolejnych latach. Jak informuje producent na swoim portalu internetowym 
(Tramwaj Tango Kraków..., 2019), nowe tramwaje poza niską podłogą i dużą liczbą udogodnień dla pasażerów będą wyposażone w specjalną konstrukcję ram wózków, zmniejszającą zużycie torowiska oraz drgania podczas jazdy, a także w przyjazny dla środowiska system rekuperacji energii elektrycznej. Krakowski przewoźnik w ramach Programu Operacyjnego Infrastruktura i Środowisko 2014-2020 otrzyma dofinansowanie w wysokości 125 mln zł na realizację tego celu. Zakup kolejnych nowych tramwajów pozwoli w przyszłości na wycofanie starych modeli wysokopodłogowych.

Miejskie Przedsiębiorstwo Komunikacyjne w Krakowie to nie tylko ekologiczny tabor tramwajowy i autobusowy, ale również inne działania zmierzające do ograniczenia negatywnego wpływu na środowisko naturalne. W ramach modernizacji zajezdni tramwajowej Nowa Huta na dachu hali tramwajowej mają zostać zamontowane panele fotowoltaiczne. Energia pozyskiwana z takiego rozwiązania ma zaspokajać zapotrzebowanie na prąd całego zaplecza obiektu. W 2017 roku oddano do eksploatacji nowoczesną myjnię z zamkniętym obiegiem wody, który wykorzystuje deszczówkę i oczyszczalnię.

W mieście również tworzone są tzw. zielone przystanki zbudowane ze starych, przeznaczonych do utylizacji słupków przystankowych oraz dużej ilości zieleni. Wtórne użycie materiałów przystankowych pozwala na kreatywne oddzielenie oczekujących na transport pasażerów od ruchliwej i zanieczyszczonej pyłami ruchliwej ulicy. Tego typu przystanki w Krakowie można spotkać np. przy Centrum Kongresowym ICE oraz w Łagiewnikach.

MPK angażuje się również w wiele ekologicznych akcji organizowanych przez miasto Kraków. Podczas takich eventów krakowskie spółki komunalne prezentują prowadzone przez siebie inwestycje na rzecz środowiska przyrodniczego. Dla przykładu można podać organizowane co roku Dni Ziemi, wielką lekcję ekologii czy Europejski Tydzień Zrównoważonego Transportu. Ponadto podczas Europejskiego Dnia bez Samochodu komunikacja zbiorowa jest darmowa, co ma zachęcić mieszkańców miasta Krakowa do porzucenia indywidualnego środka transportu na rzez komunikacji miejskiej. Warto wspomnieć również o parkingach typu park \& ride, gdzie pozostawiając swój samochód, można podróżować po mieście w ramach opłaconego biletu parkingowego. Ma to na celu ograniczenie wjazdu mieszkańców gmin ościennych do i tak już przepełnionego samochodami centrum miasta. Wszystkie te działania połączone z nowoczesnym, ekologicznym taborem mają za zadanie zachęcić mieszkańców do korzystania z miejskiego transportu zbiorowego.

\section{ZAKOŃCZENIE}

Intensywny rozwój aglomeracji krakowskiej pociąga za sobą coraz większe zapotrzebowanie na transport. Bardzo duża liczba samochodów, korki i zanieczyszczenie powietrza powinny zostać przeciwstawione sprawnie i efektywnie zorganizowanej komunikacji miejskiej. Zastosowanie nowoczesnych i ekologicznych rozwiązań w transporcie zbiorowym daje możliwość podniesienia jakości i komfortu życia mieszkańców miasta oraz ograniczenie jego negatywnego oddziaływania na środowisko.

W najbliższych latach Kraków ma w planach dynamiczny rozwój komunikacji miejskiej - budowę nowych torowisk, wymianę taboru na nowocześniejszy i bardziej ekologiczny oraz współpracę na rzecz ekologii z innymi podmiotami. Miejskie Przedsiębiorstwo Komunikacyjne dzięki efektywnemu i operatywnemu zarządzaniu jest przygotowane na prężny i ekologiczny rozwój oferowanych usług transportowych. Prowadzone 
aktualnie przez przedsiębiorstwo zakupy nowoczesnego taboru są największe w historii MPK S.A. Krakowski przewoźnik nie poprzestaje na doskonaleniu floty tramwajowej i autobusowej - w kolejnych latach w ramach programu E-bus władze Krakowa planują nabyć kolejne autobusy elektryczne.

Od 2018 roku przeznaczone zostało blisko 30 mln zł więcej na komunikację zbiorową - co ma ograniczyć do 2020 roku liczbę samochodów na krakowskich drogach. Dbałość o środowisko, komfort i jakość oferowanych usług to najważniejsze hasła, jakimi kieruje się MPK w wyborze technologii i działań zmierzających do rozwoju miejskiego transportu zbiorowego. Nowe podejście przewoźnika do mobilności - zgodne z zasadami zrównoważonego transportu - zbliża krakowską komunikację zbiorową do poziomu europejskiego. Zachowanie dynamicznego postępu w dziedzinie komunikacji gwarantuje poprawę jakości życia mieszkańców Krakowa zarówno w sferze komfortu podróżowania, jak i możliwości oddychania świeższym i zdrowszym powietrzem.

\section{Literatura}

References

Analiza kosztów i korzyści zwiq̨anych z wykorzystaniem autobusów zeroemisyjnych, w celu świadczenia usług komunikacji miejskiej na terenie aglomeracji krakowskiej - Wydział Gospodarki Komunalnej (2019, 16 listopada). Pozyskano z https://www.bip.krakow.pl/zalaczniki/dokumenty/

Bodzek, M. (2018). Zielone i społeczne odpowiedzialne zamówienia publiczne jako narzędzie zrównoważonego rozwoju transportu publicznego. Homo Politicus, 13, 115-123.

Bogacki, M., Bździuch, P. (2017). Autobusowy transport publiczny w Krakowie na tle najlepszych światowych systemów komunikacji miejskiej oraz ocena wpływu jego modernizacji na wielkość emisji zanieczyszczeń. Transport Miejski i Regionalny, 4, 26-31.

Chamier-Gliszczyński, N. (2010). Ekologiczny transport w miastach. Autobusy: Technika, Eksploatacja, Systemy Transportowe, 6, 1-6.

Fajczak-Kowalska, A., Kowalska, M. (2017) Zrównoważony rozwój publicznego transportu zbiorowego - gmina miejska Pabianice. Autobusy: Technika, Eksploatacja, Systemy Transportowe, 12, 532-537.

Fajczak-Kowalska, A., Rudowska, P., Ziemiński, P. (2017). Zrównoważony transport publiczny jako podstawa logistyki miejskiej przyjaznej społeczeństwu. Gospodarka w Praktyce i Teorii, 1(46), 27-43.

Filipowicz, J., Filipowicz, P., Zaprawa, K. (2017). Emisja zanieczyszczeń spalinowych przez autobusy komunikacji miejskiej. Autobusy: Technika, Eksploatacja, Systemy Transportowe, 9, 52-55.

Guciewski, Ł., Jóźwiak, A. (2018). Wybrane aspekty ekologii w miejskim transporcie drogowym. Prace Naukowe Politechniki Warszawskiej. Transport, 120, 143-153.

Jurga, S., Zając, G. (2017). Energochłonność pojazdów komunikacji miejskiej w Krakowie. Autobusy: Technika, Eksploatacja, Systemy Transportowe, 6, 1142-1146.

Korneć, R. (2018). System transportu miejskiego wobec zrównoważonego rozwoju. Studia Miejskie, 30, 71-84.

Kostrz, M., Satora, P. (2017). Związki odpowiedzialne za zanieczyszczenie powietrza. Inżynieria Ekologiczna, 6(18), 89-95.

Kuchcik, M., Milewski, P. (2018). Zanieczyszczenie powietrza w Polsce - stan, przyczyny i skutki. Studia Komitetu Przestrzennego Zagospodarowania Kraju PAN, 182, 341-364.

Motowidlak, U. (2015). Rola transportu miejskiego w realizacji celów gospodarki niskoemisyjnej. Studia Ekonomiczne. Zeszyty Naukowe Uniwersytetu Ekonomicznego w Katowicach, 249, 172-184.

MPK SA w Krakowie wyposażyło 6 autobusów w panele słoneczne (2019, 8 listopada). Pozyskano z http://www.mpk.krakow.pl/pl/aktualnosci/news,6614,mpk-sa-w-krakowie-wyposazylo-6-autobusow-w-panele-sloneczne.html 
Podsumowujemy 2018 rok - ekologiczna komunikacja autobusowa i umowa na 50 nowych niskopodłogowych tramwajów (2019, 8 listopada). Pozyskano z http://www.mpk.krakow. $\mathrm{pl} / \mathrm{pl} /$ aktualnosci/news,6901, podsumowujemy-2018-rok--ekologiczna-komunikacja-autobusowa-i-umowa-na-50-nowych-niskopodlogowych-tramwajow.html

Raport o stanie środowiska województwa małopolskiego w 2016 roku (2019, 16 listopada). Pozyskano z http://krakow.pios.gov.pl/stan-srodowiska/publikacje/raporty-o-stanie-srodowiska/

Rozkład taboru (2019). Miejskie Przedsiębiorstwo Komunikacyjne.

Rulaff, M. (2013). Projekt Trolley jako przykład promowania ekologicznego transportu zbiorowego. Zeszyty Naukowe Politechniki Poznańskiej, 60, 89-96.

Starowicz, W. (2004). Charakterystyka polskiej normy „Jakość usług w publicznym transporcie pasażerskim". TTS Technika Transportu Szynowego, 9, 29-41.

Starowicz, W. (2017). Nowa polityka transportowa miasta Krakowa na lata 2016-2025. Transport Miejski i Regionalny, 4, 5-12.

Statut Spółki Akcyjnej (2019, 15 listopada). Pozyskano z http://bip.mpk.krakow.pl/pl/status-spolki/document,1920.html

Tramwaj Tango Kraków Lajkonik (2019, 16 listopada). Pozyskano z https://www.stadlerrail. com/media/pdf/tmpkc0719p.pdf

WIOŚ (2018) (2019, 10 listopada). Biuletyn o zanieczyszczeniu powietrza WIOŚ (2018). Pozyskano z http://krakow.pios.gov.pl/stan-srodowiska/monitoring-powietrza/miesieczna-informacja-o-zanieczyszczeniu/

Zatrudnienie w MPK S.A. w Krakowie (2019, 10 listopada). Pozyskano z http://www.mpk.krakow. $\mathrm{pl} / \mathrm{pl} /$ organizacja/zatrudnienie/

Katarzyna Janczarska-Bergel, mgr, absolwentka Instytutu Geografii Uniwersytetu Pedagogicznego w Krakowie (2017). Doktorantka w Instytucie Geografii Uniwersytetu Pedagogicznego. Zainteresowania badawcze autorki dotyczą rozwoju regionalnego Francji, ekologii, transportu i dydaktyki geografii.

Katarzyna Janczarska-Bergel, MSc, graduate of the Institute of Geography of the Pedagogical University of Krakow (2017). A doctoral student in the Institute of Geography of the Pedagogical University. Her research interests include regional development of France, ecology, transport and didactics of geography.

ORCID: 0000-0002-6075-0167

Adres/address:

Uniwersytet Pedagogiczny w Krakowie

Instytut Geografii

Zakład Dydaktyki Geografii

ul. Podchorążych 2, 30-084 Kraków, Polska

e-mail: Katarzyna-bergel@wp.pl 